\title{
Fontes e Recursos do ecossocialismo
}

\author{
Sources et ressources de l'ecosocialisme
}

Autor: Michael Löwy

Diretor de pesquisa no CNRS (Paris)

\section{Tradução: Maria Cristina Longo}

Professora no departamento de filosofia da UFRN

\begin{abstract}
ecossocialismo é uma corrente política fundada sobre uma constatação essencial: a salvaguarda dos equilíbrios ecológicos do planeta, a preservação de um ambiente favorável às espécies vivas - inclusive a nossa - é incompatível com a lógica expansiva e destrutiva do sistema capitalista. A busca do crescimento sob a égide do capital nos conduz, a curto prazo nas próximas décadas - a uma catástrofe sem precedentes na história da humanidade: o aquecimento global.

A premissa central do ecossocialismo, implícita dentro da escolha deste termo é que um socialismo não ecológico é um impasse, e uma ecologia não-socialista é incapaz de enfrentar os desafios atuais. Seu projeto de associar o « vermelho » - a crítica marxista do capital e o projeto de uma sociedade alternativa - e
\end{abstract}


o « verde », a crítica ecológica do produtivismo, não tem nada a ver com as combinações governamentais ditas «vermelhas-verdes», entre a social-democracia e alguns partidos verdes, em torno de um programa social-liberal de gestão do capitalismo. O ecossocialismo é então uma proposta radical para atacar pela raiz a crise ecológica - que se distingue das variantes produtivistas do socialismo do século 20 - seja a social-democracia ou o «comunismo» ao estilo estalinista - sejam correntes ecológicas que se adequam, de um modo ou de outro ao sistema capitalista. Uma proposta radical que visa não somente à uma transformação das relações de produção, do aparelho produtivo e dos modelos dominantes de consumo, mas visa a criar um novo paradigma de civilização, em ruptura com os fundamentos da civilização capitalista/industrial ocidental moderna

Não é o lugar aqui de desenvolver uma história do ecossocialismo. Lembremo-nos, no entanto, de alguns marcos: o ecossocialismo será essencialmente uma questão da corrente eco-marxista, mas encontra-se na ecologia social de inspiração anarquista de Murray Bookchin, na versão à esquerda da ecologia profunda de Arne Naess, e em alguns escritos dos «oposositores do crescimento» (Paul Ariès), análises radicalmente anti-capitalistas e propostas alternativas que estão próximas do ecossocialismo.

A ideia de um socialismo ecológico - ou uma ecologia socialista - só começa a se desenvolver verdadeiramente a partir dos anos 1970 sob formas muito diversas, nos escritos de alguns pioneiros de uma reflexão « vermelho e verde» : Manuel Sacristan (Espanha), Raymond Williams (Inglaterra), André Gorz e Jean-Paul Déléage (França) e Barry Commoner (EUA). O termo «ecossocialismo», aparentemente apenas começa a ser utilizado a partir dos anos 1980 quando aparece, no partido verde da Alemanha, uma corrente de esquerda que se designa como «ecossocialista»; seus principais porta-vozes são Rainer Trampert e Thomas Ebermann. Por volta dessa época aparece o livro A Alternativa de um dicidente socialista da Alemanha Oriental, Rudolf Bahro que desenvolve uma crítica radical do modelo soviético e da Alemanha Oriental, em nome de um socialismo ecológico. No curso dos anos 1980 o pesquisador norte-americano James O’ Connor desenvolverá seus trabalhos 
tendo em vista um marxismo ecológico, e funda a revista $\mathrm{Ca}$ pitalismo, Natureza e Socialismo, enquanto Frieder Otto Wolf, um deputado europeu e dirigente da esquerda do Partido Verde Alemão, e Pierre Juquin, um ex-dirigente comunista convertido às perspectivas vermelhas/verdes, redigem juntos o livro $A$ Alternativa Verde da Europa (Montréal, 1992, Black Rose), um tipo de tentativa de manifesto ecossocialista europeu.

Enquanto isso, na Espanha, em torno da revista de Barcelona Mientras Tanto, os discípulos de Manuel Sacristan como Francisco Fernandez Buey também desenvolvem uma reflexão ecológica socialista. Em 2001, uma corrente marxista/revolucionária presente em numerosos países, a quarta internacional, adota um documento, Ecologia e Revolução Socialista, de inspiração claramente ecossocialista. Mais recentemente, em 2012, o partido de esquerda organizou em Paris, e em seguinda em várias outras cidades francesas, reuniões para discutir o ecossocialismo. Adicone a isto os trabalhos de John Bellamy Foster e seus amigos da revista de esquerda americana bem conhecida Monthly Review, que defende uma revolução ecológica com um programa socialista; os escritos das ecosssocialistas feministas Ariel Salleh e Terisa Turner; a revista Canadian Dimension, apoiada pelos ecossocialistas Ian Angus e Cy Gornik; as reflexões do revolucionário peruano Hugo Blanco sobre as relações entre idigienismo e ecossocialismo; os trabalhos do pesquisador belga Daniel Tanuro sobre a mudança climática e os impasses do «capitalismo verde»; as pesquisas dos autores franceses próximos da corrente altermundialista como Jean-Marie Harribey; os escritos do filósofo (discípulo de Ernst Bloch e de André Gorz) Arno Münster; etc, etc.

Em 2001 Joel Kovel e o autor do presente texto publicam um Manifesto Ecossocialista que servirá de referência para a fundação, em Paris em 2007, da Rede Ecossocialista Internacional. Quando do Forum Social Mundial de Belém (Brasil) em 2009 uma nova reunião internacional da rede terá lugar, com uma ampla participação latino-americana e uma delegação indígena do Peru dirigida por Hugo Blanco e Marcos Arana. Nesta ocasião será publicada, em muitas línguas, a Declaração 
de Belém, um manifesto da rede ecossocialista internacional a respeito do aquecimento global. Eis aqui algumas passagens deste documento assinado por centenas de pessoas de dezenas de países do mundo:

«O ecossocialismo implica uma transformação social revolucionária, que necessitará da limitação do crescimento e da transformação das necessidades por uma transferência radical dos critérios econômicos quantitativos em direção a critérios qualitativos, uma ênfase sobre o valor de uso no lugar do valor de troca. Estes objetivos exigem o controle democrático da esfera econômica, permitindo à sociedade definir coletivamente seus objetivos de investimento e de produção, e a coletivização dos meios de produção. Somente a tomada de decisão e a propriedade coletiva da produção podem abrir a perspectiva a longo prazo que é necessária para o equilíbrio e a durabilidade dos nossos sistemas sociais e da natureza. (...)

«Para evitar o aquecimento global e outros perigos que ameaçam a sobrevivência humana e ecológica, setores inteiros da indústria e da agricultura devem ser suprimidos, reduzidos ou reestruturados e outros devem ser desenvolvidos, enquanto fornecem pleno emprego para todos. Uma transformação tão radical é impossível sem o controle coletivo dos meios de produção e a planificação democrática da produção e das trocas. As decisões democráticas sobre o investimento e o desenvolvimento tecnológico devem substituir o controle das empresas capitalistas, dos investidores e dos bancos a fim de servir, a longo prazo, ao bem comum da sociedade e da natureza».

Simultaneamente à contra-cúpula sobre o clima em Copenhagen em 2009 ou no Rio de Janeiro em 2012, outras declarações ecossocialistas internacionais foram feitas. Em Junho de 2013, vários membros da Rede Ecossocialista Internacional, vindos da França, Bélgica, Canadá, EUA e Brasil, participaram da Conferência Internacional sobre o Ecossocialismo e o Buen Vivir em Quito, no Equador - uma iniciativa que testemunha o interesse crescente pelo ecossocialismo na América Latina. Pode-se consultar os documentos da Rede no site www.ecosocialistinternationalnetwork.org. 